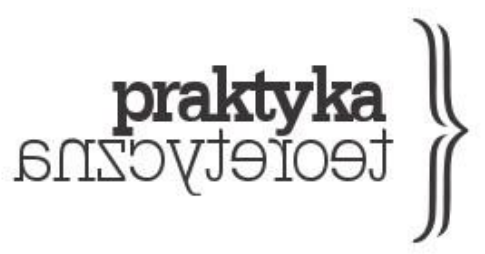

ISSN $2081-8130$

DOI: $10.14746 /$ prt.2019.1.6 www.praktykateoretyczna.pl

\title{
ERASURE OF THE COMMON: From Polish ANTI- COMMUNISM TO UNIVERSAL ANTI-CAPITALISM
}

\author{
ŁUKASZ MOLL
}

\begin{abstract}
The subject of the article is the recent rise in significance of anti-communist discourses on the example of Polish anti-communism. The aim of the article is twofold. Firstly, to test the limits of usefulness of the theory of hegemony in the critique of anti-communism. I claim that it remains operative as an analytic tool to track practical uses of anti-communism in political rivalry, but it is unable to conceptualize more systemic and non-apparent operations of anti-communist logics in the machinery of contemporary capitalism. I propose an alternative interpretation of anti-communism, drawing mostly on post-operaist Marxism of the common and acknowledging its theoretical assumptions with recent research on the Polish popular classes and their bottom-up social practices. Secondly, I present a hypothesis, according to which proper understanding of the particular example of Polish anti-communism could be helpful to understand the functioning of universal anti-communism as a reaction to the struggles to institute the common.
\end{abstract}

Keywords: anti-communism, the common, anti-capitalism, hegemony, Polish politics 
In November 2018, the President of the European Council and former Prime Minister of Poland, Donald Tusk, gave a significant speech. Speaking on the occasion of the hundredth anniversary of Polish independence in the aftermath of the First World War, Tusk demonstrated an amazing display of anti-communism. His speech can be read as a clear evidence that morbid, late anti-communism is not the specialty of the current right-wing populist Polish government, but it functions also as a main feature of the ideology advocated by the mainstream opposition. According to Tusk, the modern history of the country is dominated by a never-ending struggle between two extreme poles, a good one and a bad one - freedom versus enslavement, democracy against authoritarianism or even totalitarianism, Western modernity and enlightenment versus Eastern backwardness and obscurantism. This well-known ideological, Eurocentric, and post-colonial binary discourse, in which Poland and other so-called "Eastern European" or "Central-Eastern European" countries are in a waiting room to become "truly European" - that means, "Western European” (Grzymski 2016, 118130) - was strengthened in Tusk's speech with the Polish messianic tradition of Poland as antemurale of Christianity, Europe or democracy, according to which the historical mission of Poland is understood as defending the borders of European civilization against its Others: barbarians, nomads, infidels and other enemies (Tazbir 2004). As a consequent proponent of anti-communist discourse, Tusk decided to fill the role of Polish and European opponent with communists. According to the right-wing vision of modern Polish and European history, it is the returning spectre of communism that stood in Poland's way to "normality" and in Europe's way to unity (Majmurek and Szumlewicz 2010, 8). Tusk presented his understanding of the case in clear terms:

Józef Pilsudski, when he defeated the Bolsheviks [in the Polish-Soviet war, 1919-1921, in which Poland withstood the Red Army's march to the West and when he de facto defended Western community, the community of freedom - he not only defended the independence of our homeland against the barbarians of the East (I am not talking only about geography at the moment) - then his situation was slightly worse than ours. When Lech Walesa defeated the Bolsheviks in some symbolic sense [in peaceful transition from really existing socialism to free-market liberalism, in which the worker Walesa acted as a leader to the oppositional trade union "Solidarity"], then his situation was much harsher than ours. So, if they could defeat the Bolsheviks, then why could you not defeat the modern Bolsheviks? (Durman 2018).

Even if later Tusk denied - in one of his tweets - that by "modern Bolsheviks", he had in mind the ruling party, Law and Justice (Durman 2018), his political side didn't miss the opportunity to utilize his words for political purposes (Olech 2018). Anyway, besides the controversy concerning "real meaning" of Tusk's words, it is that indeterminacy, which is included in uses 
of the term "communism" in Polish public debate, which is the most interesting. The fact that almost everyone and everything in contemporary Poland could be named "communist", stands as a distinctive feature of Polish anti-communist discourse. Even the more popular anti-leftist label, which is distinctive to that country and structurally similar to articulations of anticommunism, is "lewactwo" (in English: "leftism") - a term which is mobilized by right-wing politicians and their supporters to connect and condemn everything which is regarded in some way as progressive, egalitarian or socialist: from the Red flag, progressive taxes, and public health care to cycle paths, political correctness, and vegetarian food (Drozda 2015).

Articulation of that discourse on the part of current opposition to the Law and Justice government is evident. The authoritarian tendencies of the ruling party, which cause protests by oppositional parties and by the European Union, were named by Tusk's allies as similar to political practices from the socialist era. In a populist way, centre-right liberals tried to build connections between the limitations of the independence of judicial power, public media, the banking sector, or exchange of cadres in governmental institutions, and the country's past. Thanks to that, they can suggest that the current electoral successes of Law and Justice and the social acceptance for reforms conducted by Kaczynski and his allies should not be explained by the failure of Tusk's former government and of the neoliberalist mode of transition. For them, it is the quasi-metaphysical, Manichean struggle between progress and communist obstacles to it that is haunting Poland today. Ironically, it is Law and Justice's government, with its paranoid anti-communism, that acts as "new communists" - this is also the label which the journal Politico decided to use on its cover devoted to Kaczynski's and Hungarian Prime Minister Viktor Orban's policies (Bayer 2018). We could enumerate many more attempts to expose Kaczynski as a "new communist". Prominent politicians and commentators try to convince Polish citizens that Kaczyński "proposes communism as in Venezuela" and his $\mathrm{PhD}$ thesis contained quotes from Lenin and Marx (Kowalska 2013), that he co-operated with the former regime's security service or that his party is nothing more than a bunch of "communists and thieves" (Koć 2018). Substantive justifications of the uses of anti-communism against the populist right are almost non-existent. Social policies, the propagandist role of public television, or electoral strategy concentrated on representation of poorer citizens from small towns and villages - all this is presented as proof of Law and Justice's communist orientation.

If we turn our attention to Kaczynski's vision of barriers to political normality, to sovereign and patriotic national community, we find the same enemy as in Tusk's imagination: communism. The same Law and Justice reforms, which Tusk associates with the Red Spectre, are justified by Kaczynski as a necessity to get rid of communist heritage, which still -30 years after the collapse of really existing socialism - does not allow the Polish country to become what it is meant to be. The violation of the Constitution was justified, because - in Kaczynski's words - "we could boldly call it a post-communist Constitution. It contains itself many 
elements that petrified the former social system and that system was nothing else than postcommunism in the pure sense of the term" (Kłoszewski 2017). The same need of renewal is advocated by Law and Justice in the personnel of institutions: exchange of judicial, journalist or academic cadres appears to be necessary, if we want to get rid of former communists, its allies, its defenders (like Donald Tusk and his colleagues) or its children - in a real or symbolic sense.

\section{Anti-communism without communists}

In both cases the functional role anti-communism plays is obvious for a Marxist-inspired analysis such as this one: it is a symptom of lack of anti-capitalism and a useful obstacle to anticapitalism at the same time. Although former functionaries of the regime lost power and disappeared from the political scene due to electoral losses and to simple time lapse, and although there is no left-wing party in the current Polish parliament, anti-communism keeps its vitality as a feature of common-sense hegemonic discourse in the Gramscian sense (Thomas 2009, 160).

The phenomenon of Central-Eastern European "late anti-communism" or "communism without really existing communists" was noted by many scholars (Herer 2017; Walicki 2005; Žižek 2009). Anti-communist narrative on the region's past delivered one of the most important components for construction of new national identities and helped to legitimize proWestern, pro-liberal-democratic and pro-capitalist policies. If for the Western part of Europe it was a common victory over fascism that gave it collective memories and visions for the united future, then for the Eastern part of the continent it was the struggle with communism and emancipation from Russian dependence that played a significant role in constructing national identity in the region and bringing reservations about "Europeness" (Judt 2011, 45-82). That's why the Othering and self-Othering of Eastern Europe is both temporal and spatial: coming to the East is not only like coming to another worse - world, but also like coming to the past, and that means - coming to the communist past (Prozorov 2011). The contamination of anti-communism and orientalism makes of the region's past and memories a spectre of the dead, which hangs over the living.

Still, in my article I would not limit myself in interpreting anti-communism only as a Eastern European specialty or as a topic for historians of the Cold War era, who still dominate studies on anti-communism (Ceplair 2011; Woods 2004; van Dongen, Roulin and Scott-Smith 2014). Although anti-communism in countries like Poland and Hungary is the most spectacular, I claim - following Jodi Dean (2019) - that it is not an issue that can be contained to some historical epoch or in a geographical area. On the contrary: in global capitalism anticommunism plays a more hidden and at the same time fundamental, systemic role for the 
reproduction of capitalist social relations. If I place my focus on Poland it is not to discover some national or regional particularity. On the contrary: I treat that particularity as a forceful exposition of the ideology of contemporary capitalism, as one of its symptoms, which can help us to re-think perspectives for much-needed new anti-anti-communist political universalism. If the real targets of anti-communism are not communists or radical Leftists, if it operates as a discourse of exclusion of nearly all political forces, where's the point in its constant reproduction?

\section{Anti-communism as anti-anti-capitalism}

I can agree with the interpretation that in contemporary Poland - where both sides of the Parliament shout at themselves "Off with the commune" and where the former persecutor of the socialist regime is a main proponent of the decommunisation of the juries, a Law and Justice deputy - the word "communism" has become an empty signifier, in the meaning which Ernesto Laclau and Chantal Mouffe ascribed to the term in their theory of hegemony (Golinczak 2019). It is true that "communism" became drained of meaning, that it ceased to mean anything substantial and that it is right now an abstract, empty term to signify almost everything (Laclau, 2007, 36-46). It is also correct to claim - drawing on Laclau and Mouffe further still - that even if anti-communism is suffering from lack of meaning, that quality is what makes it really useful: as an empty signifier anti-communism delivers a symbolic frame for collective meaning, for articulation of political divisions, and it functions as a adjourned promise of "fulfillment of society" (Laclau and Mouffe 2001, 111-113). That fulfillment is only postponed because there is some kind of remnant, some stubborn obstacle, an Other, which is regarded as the cause of social antagonism. For oppositional center-right politicians it would be the new authoritarian communism of Kaczynski as a continuation of the country's communist past, and for ruling right-wing populists like Kaczynski it would be the sin of neglecting decommunisation after 1989 that makes anti-communist policies necessary today.

But even if the discourse analysis inspired by Laclau and Mouffe's philosophy remains operative in understanding the reproduction of anti-communist discourses in Poland - and I think it does - I claim that it is nevertheless insufficient to explain its necessity and also its truly universal, functional role for capitalist accumulation. In what follows I utilize the theory of hegemony, but I try to go further than this. Drawing on Slavoj Žižek's (2000) critique of Laclau and Mouffe I ask about deeper, material conditions, which had to be fulfilled for the play of signifiers in which anti-communism could be filled out as a structural empty signifier for political discourse. I test a hypothesis that it was the expulsion of collective anti-capitalist practices that structured Polish post-communist discourse in an anti-communist fashion. Following Žižek $(2000,92)$ and contrary to Laclau and Mouffe, I differentiate two kinds of 
voids in discourse reality. The first one: a void that constitutes a system of social meaning as such. The second one is Lefort's empty place of power (Lefort 1988, 225), around which many discourses (including many anti-communist discourses) concentrate. Laclau and Mouffe's theory of hegemony is limited only to the second void. Žižek's postulate - which I share with him - is to open analysis to deeper, material transformations, which in the case of Poland are easy to track. It was the restoration of capitalism in its neoliberal version, launching the processes of "continuous primitive accumulation" of capital (De Angelis 2001), possible thanks to the vast scope of public, socialist goods, that made anti-communism so useful to legitimize the transition (Klein 2007, 171-282; Rae 2008: 6). But the extreme and marginal example of Poland (and other post-socialist countries) could help us at the same time understand the workings of a universal mechanism: anti-communism - sometimes evident and proud (as in the Eastern Europe), but mostly hidden and systemic - is first and foremost anti-anticapitalism. This is because anti-communism - as we may clearly see in contemporary Poland functions as a pacifier for leftist critique of capitalism and at the same time it delivers a competitive answer in trying to identify the cause of social antagonism. If anti-Semitism was (and still is) "the socialism of fools" - as German socialist August Bebel famously observed today anti-communism plays the role of "the anti-capitalism of fools". Instead of criticizing capitalism - in the context of its wide-ranging restoration in society - anti-communism redirects attention to the communist past, internal and external conspiracies, or multiple "new communisms", which threaten Poland's survival and development.

In what follows I try to justify - based on examples of contemporary anti-communist discourses in Poland - two theses. First: the success of anti-communism in post-socialist countries was possible not only due to convincing rhetorical demonization of the socialist era, but also - and mainly - thanks to the constant eradication of articulations of the common. Erasure of the common - what I call all processes of suppression, undermining and concealment of bottom-up practices of solidarity and co-operation - interestingly connects socialist bureaucracy to the new political elites, and depends on rejection of popular demands and attempts at self-organization. The image of enslaved society, which is promoted by the Right. can be maintained only if we substitute collective subjectivity with universal subjection. Second thesis: the analyzed mechanism is of actual importance not only for the post-socialist countries of Central-Eastern Europe. Its universal reach is most apparent in case of furious anti-communist political leaders in other world regions: from Donald Trump and the Tea Party's America to Bolsonaro's Brazil and Duterte's Philippines (Wielgosz 2019). But I treat all these far-right crusades against communism as a tragicomic disclosure of contemporary capitalist logic: if today's accumulation of capital depends on continuous enclosures of the common (from privatization and restriction in access, through plunder and financialization of goods, to subsumption of collective labor and crushing the resistance) (Mezzadra and Neilson 
2017), which Sandro Mezzadra and Brett Neilson call "extractivism”, then anti-communism understood as erasure of the common - is much needed by capital as its ideological vehicle.

In conclusion I try to convince the reader that the strategies of cutting itself off from communism tested by the Polish Left are not only ineffective, but even counter-effective. By trying to avoid communist connotations, the Left only strengthens anti-communist hegemonic discourse. But it is also unproductive to simply try to regain communist symbols, phrases, or patrons without understanding that what we need to reclaim to defeat anti-communist today is not necessarily a sickle and hammer on the Red Flag or monuments of Vladimir Lenin - it is the common. In the final part of the article I bring some attention to recent research on the history of really existing socialism in Poland, conducted by engaged left-wing scholars. I claim that their re-interpretations of modern history, in which bottom-up struggles for the common take a fundamental place, help us to re-orientate the collective perception of socialism. It is in their discoveries of the commons under socialism that we can find an inspiration for articulation of the common today, in Poland and everywhere else.

\section{Poland: from post-communist neoliberal compromise to decommunization}

The socio-political context, in which it is impossible to locate sources of anti-communist discourses in the Polish public sphere after 1989, is marked by a neoliberal model of transition. As many critics of Polish neoliberalism convincingly showed, political elites decided to choose a shock-therapy course for reforming the country after the end of socialism (Hardy 2009; Kowalik 2012). That course generated high social costs and anger from a wide range of groups, who had previously expected that the government originating from the former massive proworkers social movement "Solidarity" would provide policies focused on the social needs of the majority of society.

This anger, related to policies of privatization of public enterprises, a dramatic increase in structural unemployment, commercialization of social services, marginalization of trade unions or alienation of former leaders of civic and workers' opposition from its social base, brought electoral consequences only four years after the first partly free and fair parliamentary elections, in which "Solidarity" noted stunning success and took responsibility for governing the country. The rapid come-back of former communists to power by 1993 did not mean an end to neoliberal policies. Post-communists were less dogmatic in implementing free-market reforms, but they were not prepared to change the course of transformation (Shields 2012, 367-368). Firstly, this was because post-communism had to legitimize itself as a political force, which was now pro-democratic and ready to reform the country. Every attempt to slow down the neoliberal course would be judged as a betrayal to historical compromise on starting the transition and as a proof of ever-lasting communist danger. The second reason for post- 
communist's readiness to continue policies which were deepening inequalities and worsening the working-class situation was more prosaic. It was in the post-communist elite's own material interest to convert all types of capitals (economic, social, cultural and symbolic) derived from the former system to new patterns of legitimacy of high social position. Neoliberal policies gave them a huge opportunity to appropriate economic capital, to utilize contacts, management competences or knowledge of foreign languages - the majority of society didn't have such opportunities (Staniszkis 1991, 47).

If the dominant political division between post-communists and post-Solidarity couldn't contribute to restraining neoliberalism, there arose a possibility to intercept social discontent in a new direction - that chance was utilized by the right-wing, anti-communist side of the opposition. In those circumstances, in which neoliberalism functioned as an unquestionable dogma and with post-communists in power, it was easier to blame the communist past for failures of implemented policies (Holubec and Mrozik 2018, 13-14). Social anger could be articulated by right-wing parties, which blamed former communist politicians, juries, cultural elites, or entrepreneurs for the unsuccessful road to a politically and economically fair system. We have to admit that right-wing politicians were often correct when claiming that the model of transition, which communist rulers negotiated with leaders of opposition in the latest years of socialism, enabled former members of the communist party to play parasitical roles in society. The peaceful process of transition, which was celebrated as a great success by former communists and by leaders of the opposition - and which was praised by foreign commentators - was regarded by right-wing circles as a betrayal. At the beginning of the 1990s they demanded launching the program of the so-called "decommunisation" (Millard 2010, 20): to judge those functionaries of the socialist regime who were guilty of repressions, and to prevent former communists from maintaining their power. Policies of decommunisation were abandoned by the first democratic governments because conditions of political transition in Poland were based on a mutual obligation that the communist party would have allowed opposition to take part in political process, but the people of the former regime could in return participate in politics as well.

The discursive role anti-communism played in the 90s allowed it to criticize reforms and to canalize social discontent and desperation, but at the same time it sustained the image of capitalism-to-come as the American dream. As political scientist David Ost (2005) showed in his book Defeat of Solidarity, the famous Polish trade union "Solidarity", which was the main oppositional force in the final years of socialism and which, during that time, was the proponent of democratic, participatory socialism, betrayed workers by supporting neoliberal reforms. "Solidarity" continued to organize the workers and to call strikes when Polish industry was privatized or liquidated and when unemployment rose from an almost non-existent level in socialism to 20 percent in the year of 2000. But what "Solidarity" demanded during the 
transition was not democratic socialism anymore, but "true capitalism". By "true capitalism" or "normal capitalism" they meant the Western model of well-being, which was not understood as a welfare state, as post-war compromise between classes, but as a truly free market economy, in which everyone has identical opportunities to lead successful life. And as the main barrier to reach "true capitalism" "Solidarity" recognized communism - the fact that the legacy of socialism was still haunting the new political reality. The structural function discourse on "normal capitalism" played was truly phantasmatic and the heritage of communism was in that context regarded as a relict that stood in the way of modernity, well-being, the West, Europe etc. - to all those values and properties that were supposed to be embodied in the postcommunist capitalist project.

What's worse, this kind of "worker-driven anti-communism" was not limited to the fight with the persistent political, economic or cultural importance of post-communist elites. Ost showed that the fact that the Left was associated simply with former communists, and that everything which was leftist - from communism and socialism to working-class and public ownership - was now despised as totalitarian, brought from abroad, and strange to Polish culture, bound trade unionist anti-communism to the political Right and the Catholic Church. That kind of anti-communist paranoia had terrible consequences for the perspectives of any type of left-wing politics in Poland. When Polish society suffered from neoliberal reforms, social anger was directed not against capitalism, but against communism and other external threats which were regarded as a danger to "normal capitalism". As Polish left-wing journalist Przemysław Wielgosz (2017) rightly pointed out, in Poland discourse of anti-communism is a basic structural feature of all discourses of exclusion. Anti-communism plays a role structurally similar to the traditional uses of anti-Semitism: it refers to the phantasm of "the Other", which has to be stopped at all costs. No wonder then that one of the most popular right-wing anticommunist constructs is "Żydokomuna" (in English: Jew-Communist). Ironically drawn from communist nationalist propaganda, the conspiracy theory of "Żydokomuna" indicates that communism is basically an ideology of modern, secularized Jews, who are natural-born enemies to Polish essentialist identity (Gerrits 2009; Gross 2007, 192-244). But structural connections between anti-communism and other discourses of exclusion go even further. Proponents of anti-communism in Poland believe that feminism or "ideology of gender" is also a "communism in disguise" or it is a manifestation of "cultural Marxism" (Czerniak 2013). The same arguments work with LGBT rights, ecology ("Green is the new Red") religious tolerance, or openness to refugees. As we have learned lately from public television, when the two hundredth anniversary of Karl Marx's birthday was celebrated abroad, according to right-wing journalists Marx was responsible even for Nazism and the Holocaust (Leszczyński 2018). As former Foreign Minister in Law and Justice's government Witold Waszczykowski elaborated in an interview with German daily newspaper Bild: 
We just want to heal our country of certain diseases. The previous government applied a left-wing concept. As if the world, according to the Marxist model, must move in only one direction, towards a mixture of cultures and a world of cyclists and vegetarians, which stands only for renewable energy and combating all forms of religion. This has nothing in common with traditional Polish values (Cienski 2017).

It is hard to find a better manifestation of right-wing all-encompassing anti-communism, which mixes together nearly all possible progressive discourses.

\section{Anti-communism as empty signifier}

Anti-communist demonization has an even wider scope than just left-wing ideologies. Regularly Polish liberals and centre-right parties, which are the main proponents of neoliberal capitalism, are being attacked by the Right as communist enemies of the country, because in the past they were opposing decommunisation and now they are slightly more open to feminism or immigration than the ruling Right. Liberals, in their turn, repay the Right with the same argument: Kaczyński and his colleagues are the real authoritarian communists, who are rebuilding the former regime in Poland. Accusations of communism remain mutual and they contribute to two dominant forms of anti-communism: the first is liberal-modern and the second is conservative-nationalist. For liberals it is the Eastern aberration of socialism, treated as anti-modern backwardness, which effectively blocks passage to European modernization. For the national Right socialism was counter to Polish identity and culture and that's why it had to be installed from abroad. In both versions of anti-communism, there is some kind of blockage, some phantasmatic abnormal Other (the past, the stranger, the Jew, the East), which can legitimize really existing capitalism as "untrue capitalism" or "corrupted capitalism". If we get rid of that blockage - the story goes on - we could finally reach "normal capitalism", which will be fully compatible with modernity (for liberals) or with the Polish tradition of hard work, family values and national community (for conservatives).

As for the Left, the situation isn't much better. The post-communist party, which is a direct successor of the former regime, was always ready to defend its people and their positions in society against "decommunisation", but as a Third Way social democracy their neoliberal policies created a demand for right-wing anticommunism. However, the main problem with the post-communist fight with anti-communism is that it defends people of the former regime who may be perceived by society as authoritarian, conservative, anti-workerist or subordinate to the Soviet Union. Post-communist narration brings confirmation to hegemonic anticommunist interpretation of contemporary Polish history, even if it is sympathetic to the injustices ordinary beneficiaries of socialism (lower-ranking officials, teachers, soldiers, workers from privatized factories) suffered after the year of 1989. 
As for the new Left, which has its roots in the opposition to the socialist regime or in new social movements, their usual attitude to the socialist era is ambivalent. Even if they appreciate social security or modernizing efforts of that era, they highlight notorious violations of human rights and pacification of the working class' protests. They are not very fond of postcommunists, but generally they're not supporting decommunisation. The non-post-communist Left constructs its identity on the tradition of democratic intelligentsia oppositional to the socialist regime, in workers' movements like "Solidarity" and - before the Second World War - on patriotic socialist parties which had an unfavorable attitude to the Soviet Union and the communist movement. But the main problem with the strategy of the new Left is that in actively and hysterically avoiding any associations with communism it contributes to the success of right-wing hegemony. Its anti-communism is not straightforward - it is more hidden and subtle, but nevertheless it has performative efficiency for the reproduction of communism as evil force and constant threat to Polish democracy and identity. When the Left is being attacked by the Right as "communist", it reacts with a mixture of indignation and abashment. For example, when politicians of the main party of the new Left - Partia Razem - were described by its opponents as "communists", they decided to go to court and to demand apologies for defamation (Szczęśniak 2017). We need to stress that these gestures of capitulation and self-restraint are made in the conditions of total right-wing hegemony, built on anti-communist consensus, which is actively shared by all sides of the public debate. Despite this the Left decides to play with defensive tactics - which we could label as "left-wing anticommunism" - and it is brought to the corner by its opponent. It is a totally opposite strategy to the right-wing one. Right-wing politicians employ a consequent offensive strategy of establishing their own ideas, symbols or heroes, even the most controversial and inappropriate ones.

That strategy works largely because of anti-communism. For example, the right-wing idea of the socialist era as a totalitarian one, during which the whole society was enslaved by inhuman ideology, brought to the country from the East, with the betrayal of the Western allies and with the help of internal traitors, helped the Right to establish a real cult of the so-called "cursed soldiers". The fact that communist rulers indeed repressed soldiers of the anti-fascist resistance after the Second World War was used by the Right to worship far-right, and in part openly anti-Semitic and pro-Nazi, anti-communist soldiers as well. The cult of "cursed soldiers", which quickly spread among Polish youth, mainly young men, was developed not by Kaczyński's ruling Right, but by the former president of the country, Bronisław Komorowski, who came from centre-right party Civic Platform. The ideological content of the cult of "cursed soldiers" is not only anti-communist and nationalist. It is connected to other cultural wars waged by the Right, starting with the "war with gender", conducted mainly by the Catholic Church and conservative politicians, or with the campaign "stop the islamization of Europe" 
(Bobako 2017, 22-23), whose proponents feel just like the real heirs of the cursed soldiers: the cursed soldiers fought with the communist plague from the East, and now there is a plague of Islamic despotism and terrorism, supported once again by external powers in Brussels and Berlin and by internal enemies of the nation, lefties and liberals (Pielużek 2016, 84).

The extreme and recent form of anti-communist policies, implemented by Law and Justice's government, includes massive, systemic erasure of the traces of the communist past in public places. The right-wing government conducted a process of re-naming streets, squares, or public institutions and literally destroying monuments and memorial plaques connected with communist figures, symbols or ideas (Niemitz 2016). In that case it can be convincingly shown that the real target of anti-communism is not communists, which are almost non-existent in Poland, especially as organized formation. During that governmental action the Polish public sphere lost the memorial of Rosa Luxemburg located at her family home in the city of Zamość, and the monuments of the Soviet Red Army, which freed Poland from Nazi occupation. Other victims of decommunization included Polish socialist patriots, participants of the international brigades in the Civil War in Spain, or people of culture who simply lived and worked during the socialist era (e.g. famous economist Oskar Lange). Decommunisation is not limited to reorganizing the past - we could mention a precedent, which was a visit of police to the Marxist scientific conference in Pobierowo (Luxmoore 2018). Through these acts of deprivation of collective memories and practices, the Right gained huge space to promote its own discursive hegemony.

The dynamics of anti-communist discourse in Poland can be successfully analysed by Laclau and Mouffe's theory. Their conviction that in a post-communist world, where conflicts on redistribution of wealth become secondary, it will be the populist right that becomes the new force of antagonism, finds strong confirmation in Polish politics (Mouffe 2005, 64-72). The theory of hegemony has a potential to explain how anti-communism could play a role of empty signifier, which shaped political common sense and patterns of exclusion. By supporting anti-communist narratives, all political forces helped right-wing populists to promote a story of universal corruption of Polish society, which needs wide-ranging renewal. Anti-communist narratives allow them to delegitimize a political opponent, to reject his claim to participate in political life. That's why it would be reasonable not only for the Left, but for all political sides wanting to create conditions for democratic debate, to tame the anti-communist offensive of the Right by taking a stance Clifford Geertz (1984) labeled as "anti-anti-communist". That point is interestingly elaborated by Wielgosz, who explains the limits of Polish democracy by its anti-communist shadow:

[A]nti-communism does not need the crime of communism and does not protest against its perversions. It is not the state terror, secret police, surveillance, persecution, torture or censorship that deter anti-communists. In fact, they make up their own 
political program. Their number one enemy is the emancipatory promise of communism, its utopian potential, radical social criticism, in a word, everything that is best in the communist project. The hatred of democracy, women's rights, economic equality, recognition of minority rights, internationalism, multiculturalism and subordinate political subjectivity is the quintessence of anti-communist attitude. And this is how anti-communism reigned in Poland after 1989. It was on the anti-communist consensus that "Polish democracy" was built, which was, from the beginning, deformed, shifted to the Right, steeped in nationalism, and on the other hand, deprived of its emancipatory, popular foundation and social content. In fact, it was democratic only formally (Wielgosz 2017).

Wielgosz's observation is consistent with the more general assumption made by Marcel Liebman and Ralph Miliband (1984), that throughout history anti-communism was used by forces of tyranny and reaction - not democracy and freedom.

\section{How empty is an empty signifier? How discursive is anti-communism?}

The theory of hegemony has undeniable merits. It allows us to understand the logic of exclusions generated by anti-communism discourses in the realm of parliamentary democracy. But is it equally useful as a theory of legitimization of capitalist social relations, of capitalist restoration - as in the case of Poland? I have serious doubts. With Laclau and Mouffe we could indeed analyze anti-communist defamation of the Left and political opponents as such in the circumstances of neoliberal order, which are beneficial for right-wing populists and their anticommunist ideology. But we remain helpless in trying to explain the structural connection between anti-communism and prohibition of anti-capitalism. In fact we could reasonably criticize the post-Marxist theory of hegemony for legitimizing capitalism as a neutral, almost natural context for politics.

I've already admitted that in my reservations to Laclau and Mouffe's theory I follow Žižek's critique. The Slovenian philosopher rightly pointed out that the authors of Hegemony and Socialist Strategy are unable to present any positive conceptualizations of capitalism. Capital is for them a force of social heterogenization, which creates drive for new social identities and movements and new lines of political antagonism. Laclau and Mouffe remain critical of the capitalist tendency to produce inequalities and social exclusion - that's why they remained advocates for left-wing policies - but they refuse to think about non-capitalist alternatives and social struggles, which could be predestined to move beyond capital. Žižek claims that Laclau and Mouffe's arguments may stand only if we are ready to deprive capitalist contradictions of their role as fundamental basis of society. And Laclau was ready to take that deciding theoretical step to justify his theses. The Argentinian philosopher regarded Žižek's insistence to treat logic 
of capital as the Lacanian Real - a dimension that makes every social order unstable and unfinished - as a vulgar Marxist residue (Laclau 2000a, 201-204).

I sympathize with Žižek's attempt to demonstrate that an empty signifier is never empty as such, that it conceals another level of deep reality. But at the same time I rate Žižek's own proposition to theorize that deeper level as inadequate. Laclau rightly replied to Žižek that 1) capitalism cannot be the Real, because it is possible to represent it in Symbolic order (Laclau 2000b, 291); 2) Žižek cannot define capital/the Real as a positive entity and thus he cannot propose transformation to post-capitalism (Laclau 2000a, 206). If we get to that impasse, we should ask: what if it is not capitalism that it is unrepresentable, unspoken, incomprehensible? What if - for Laclau and Mouffe, and also for Žižek - it is their inability to deliver any prospects of communism, that makes their theories secretly and incautiously anti-communist?

To avoid the risk of naturalizing capitalism, we need to define anew the status of communism in relation to capitalism. If communism had to be some kind of void, which troubles capital and which endangers its existence, it could not be defined as suppression of capitalism, as a result of its internal tendencies (e.g. development of productive forces).

Negative conceptualization of communism - as Lacanian Real, as unsuccessful remnant of symbolization - gives us no indications what communism may look like. Žižek's reading says to us only that capital will experience deep ruptures and crises in the future, but is such an observation such revolutionary as it seems to be? Is it not simple confirmation of capitalist selfknowledge and - even more - one of its main virtues, as regarded by its advocates? The fact that capitalism is identical with crisis give us no hope for its suppression - rather it communicates to us that after every recession a new phase of economic boom will come.

Also, Jacques Derrida's (1994) well-known spectral theorization of communism regarded as a promise and demand for justice, which is inherent to capital - gives us no possibilities to unleash communism from capitalist command. Derridean spectres of communism cannot materialize themselves, even if they are impossible for capitalist powers to exorcise. Deconstructive communism is necessary as a capitalist ghost, but aporetic as an alternative social order.

To define anti-communism not as a particular feature of politics in post-socialist countries and not only as a discursive phenomenon, but as a structural feature of capitalism, I propose a post-operaist reconceptualization of communism as the common. Following Hardt and Negri (2009, 181-182) I treat the common as the affirmative drive of beings to cooperate, to be together, to love, to desire, to create, which capital needs to eradicate to stop any serious attempt to move beyond its horizon. If we follow theoreticians of the common, we would realize that capital constantly feeds on the common, which is always in excess, always beyond every form of capitalist valorization, always in priority as an active force for collaboration before it is subjugated, smashed, organized by the capitalist mode of production. 


\section{Erasure of the Common: in search of a new conceptualization of anti- communism}

From the perspective of continuous enclosures of the common, anti-communism appears to be not some strange aberration, which is present only in countries with a socialist past or with strong leftist traditions, but a persistent effort to contain all possibilities of autonomization of collective production. By concentrating our attention on anti-communist spectacle conducted by far-right leaders, we are unable to grasp that baseline character of anti-communism, understood here as anti-anti-capitalism. But is it really the case in a country with weak progressive political forces - such as Poland - that we can speak of excessive articulations of the common? Where to seek them?

Michael Hardt and Antonio Negri $(2009,107)$ proposed to conceptualize the common beyond the private and the public, beyond capitalism and socialism. From their point of view, private and public goods alike are entangled with the regime of property. The authors of Commonwealth regard them as corrupted forms of the common (Hardt and Negri 2009, 159164). If that is really the case, we are free to distance ourselves from the outmoded dispute between really existing socialism and really existing capitalism or from the whole problem of transition from the public to the private regime of property, and instead of it devote our attention to the joint struggle, in which capitalism and socialism hand in hand try to marginalize their common enemy, which is the common. Communism - or, to avoid misunderstanding, commonism (Dockx and Gielen 2018) - is alien both to the regime of private property, in which the common suffers from privatization, commercialization and capitalist competition, and to the regime of state-owned forces of production and hierarchical rule of the party. If we agree on the above conceptualization of communism/commonism, socialism and capitalism, it will become evident that anti-communism, understood as erasure of the common, lies in the interest of capitalism and socialism alike, and that it was the inability of socialist regimes to deal with this accumulation of being which caused the collapse of the Soviet Bloc (Negri 2008).

If pure theoretical argument for such a change of perspective remains unconvincing and I think so - then there appears a necessity to ground it in empirical research. Fortunately, in the last years many researchers have been trying to regain forgotten or marginalized experiences of the collective struggles and agency of the popular classes in Poland. It is their researches I would like to evoke in order to justify my thesis that the basic form of anticommunism in Poland concerns erasure of the common and that the anti-communist spectacle of the Right, which became the dominant, hegemonic narrative, is only the most visible trace of fundamentally ousted commonist history from below. The real Red threat for the Polish model of neoliberal capitalism lies not in some former bureaucrats or monuments of Red Army's soldiers, but in collective practices of solidarity and mutual support. 
Coming to research projects, in which I find support for my elaboration, it is impossible to skip Michał Siermiński's book Dekada przełomu, in which the author showed how between the years of 1968 and 1980 the most important intellectuals of the left-wing opposition abandoned ideals of participatory socialism, which were present in the program for "Selfgoverning commonwealth" from October 1981. But despite these ideals, intellectuals tried to establish their conservative ideological guardianship in relation to workers. Siermiński (2016) claims that in the final years of really existing socialism the former radical intelligentsia took over leadership of the opposition, concluded an agreement with the regime and started antiworkers neoliberal reforms. The proletarian common was caught, transformed and finally corrupted by oppositional "anti-politics". The paternalistic attitude to Polish workers - treated by intellectuals as "subalterns", who cannot speak for themselves and who have to be represented by external actors - expropriated the working class from their legitimize influence on politics during the transition era. The most self-evident form of erasure of the common was the engagement of intellectuals in convincing the workers of the need to cease to continue strikes in workplaces. The so-called "wild, uncoordinated strikers" were regarded by intellectuals as a sign of workers' irrationality, immaturity and irresponsibility. And the symbolic displacement of the proletarian character of "Solidarity" came after 1989, when history of the movement was rewritten in nationalist ("movement for national independence"), liberal ("movement for civic society, freedom and human rights"), Catholic ("movement for religious renewal") and anti-communist terms ("movement against totalitarian ideology and regime"). Symbolic erasure of the common was functional for implementing neoliberalism, because it helped to marginalize the proletarian tradition of resistance in the era of transition. The most explicit elaboration on workers' passivity and inability to govern themselves was present in Józef Tischner's writings. A priest and philosopher, who was a spiritual ally for "Solidarity" and theorist of "ethics of Solidarity", he proposed an influential anti-communist and antiworkerist narration on the Polish common man, in which he was called "homo sovieticus": a self-reliant, enslaved and unmannerly type of subjectivity, who needed to be educated by the new social reality (Tischner 1992, 141-145). If a worker was a "homo sovieticus", it was the role of elites to restrain him and show him a path to freedom and well-being.

Sociologist Wiktor Marzec in his book Rebelia i reakcja directed our attention to the fact that this kind of patronizing relationship between the intelligentsia and the popular classes was a constant structural feature of the Polish public sphere from the beginning of the twentieth century. Marzec (2016) convincingly showed that we should search for the genesis of this elitist public sphere in the Revolution of 1905 in Russia, which also covered workers from the Polish part of the Tzardom. Workers' rebellion and perspective on communism caused fear in Polish intellectuals, who started to see their role as political representative and educator of the proletariat. In conclusion to his book Marzec proposed a hypothesis that the strongly 
hierarchical shape of the early modern Polish public sphere survived through Polish history. The author brought our attention to the phenomenon of structural similarity between the elitist attitude to workers during the socialist era and in the transformation to capitalism. From his point of view, Polish anti-communism and efforts towards erasure of the common are as old as capitalist modernity itself.

Other authors showed that despite these efforts, we could find many manifestations of the plebeian commons in modern Polish history. Jan Sowa - in his part (2015) - provocatively described the "Solidarity" movement in the terms of Alain Badiou's philosophy as a communist event (Majmurek, Mikurda and Sowa 2011) and as an ambitious attempt to institute "the common" as theorized by Hardt and Negri. Sowa claimed that despite its seemingly anticommunist language, symbolism, and alliances (the Catholic Church, right-wing politicians, capitalist countries), the internal structure and logic of daily functioning of "Solidarity" in the years 1980-1981 (before its pacification by martial law) could be regarded as an impressive effort to realize the regime's promises in full shape. The massive, cross-sectoral character of the independent trade union "Solidarity" gave it possibilities for real socialization of the means of production and communication and of the national workforce. Sowa repeated a thesis formulated famously by a leading oppositionist, historian Karol Modzelewski, that without the pacification of "Solidarity" in the early 1980s, neoliberal reforms in the 1990s would be simply impossible, because the workers' movement would stop them in their tracks.

It was due to ideological displacement that the workerist character of the "Solidarity" movement became marginal and "Solidarity" started to be regarded as a collective subject of anti-communist politics - in religious-nationalist or civic-liberal versions. Feminist philosopher Ewa Majewska described that process in terms of passing from an inclusive and bottom-up "proletarian public sphere" (as developed by Oskar Negt and Alexander Kluge) to an exclusive and top-down "liberal public sphere" (as conceptualized by Jürgen Habermas). In her book Kontrpubliçności ludowe i feministyczne, Majewska (2018) also adopted Gayatri Chakravorty Spivak's theory of "the subaltern" and Nancy Fraser's "subaltern counterpublics" to enrich our understanding of political desubjectification of workers with feminist and post-colonialist theoretical perspectives. According to Majewska, many counter-audiences of the subalterns from women, who actively participated in "Solidarity", to workers, who were much more independent and self-aware than the intelligentsia were ready to admit - in dominant discourse became expropriated from their collective past and present agency, because their political presence became seen as non-legitimate, atypical or even apolitical. Women and workers are regarded as subalterns, because in the liberal male bourgeois public sphere their modes of presence appear immature and demanding of special care, attention and - as a consequence proper representation. Contrary to fatalist narration on successful pacification of subalterns, Majewska tried to present recent political protests of women and their male allies against 
repressive abortion laws as a constant reproduction of "weak" and "unheroic" resistance, which is typical of subalterns' marginal subjectivity and agency.

Some researches on popular subjectivity let us discover that articulations of the common were possible not only in the most open, but brief period of intensive struggles, described as the "carnival of Solidarity". They were happening even in the darkest times of Stalinism. Thanks to the book by Padraic Kenney (1997) on relations between Polish workers and communists directly after the Second World War, separate researches conducted by Małgorzata Fidelis (2014) and Magdalena Grabowska (2018) on the role of Polish women in socialist regime, or the monograph by Agata Zysiak (2016) on the emancipatory promise of socialist university, we can see that even during the Stalinist era in Poland, the popular classes had the potential to articulate their own collective will and to use the emancipatory promises of the system to their own advantages. Kenney proved that even in the final months of the Second World War and in the first five years after its end, Polish workers were able to present their collective power to their self-proclaimed ideological representatives from the Communist party. Their ability to organize and strike - strengthened by collective knowledge gained in antifascist resistance - gave them possibilities to fight for their rights. Kenney's theses forcefully questioned classist narration on the Polish worker as "homo sovieticus", whose subjectivity works like an additional part to the machine. Polish workers, since the very beginning of the socialist regime, were ready and able to take the production process into collective control and to institute the common in factories. The merit of Kenney's argument lies also in his insistence on the continuation of the tradition of resistance and co-operation between the inter-war and post-war eras. It was in cities with continuous industrial and proletarian character - such as Łódź - that the common caused real trouble for the self-proclaimed workers' representatives of the socialist state.

The same can be said of female post-war workers, who were subjected to research by Fidelis. If, according to Kenney, workers were in some sense more communist than the communist party, we could say that according to Fidelis, female workers were more left-wing feminist than the mode of female emancipation advocated by the regime. They tried to gain resources and to strengthen their social status, which was offered to them by reforms, but at the same time they were aware of many gender injustices and inequalities that were retained in socialism. Grabowska - in her part - completed this image of challenges to post-war women's emancipation by examining the role female communists played in the party and women's organizations. Grabowska rejected the anti-communist cliché of forced participation of women in socialism. She brought many empirical arguments to prove that women in massive numbers joined the party, the League of Women and generally worked for the regime because they wanted to and because they conceived of it as an opportunity for emancipation. At the same time, they were critical of many elements of the new reality, which were opposed to official 
ideology, e.g. gender wage inequalities, underestimation of reproductive labor, or sexist prejudices, and they intervened whenever there was a possibility of bringing progressive changes. Revisionist feminist scholars point out that in erasing the tradition of radical leftist feminism, contemporary mainstream liberal feminism - intentionally or not - supports anticommunist hegemony in Poland (Mrozik 2014; Szopa 2019).

Similarly, even in not completely successful projects like emancipation through higher education in post-war years, researched by Zysiak, we could still see tensions between many political actors, who tried to utilize the regime's ideological discourse and implemented reforms for their own benefits. As in factories and in households, new possibilities under socialism brought radical hopes to some factions at socialist universities. Promises of redistribution of knowledge, of generational advancement of civilization, and of tearing down the wall between abstract academic science and the concrete life-worlds of the popular classes, inspired progressive professors and unprivileged students alike. And as in factories and in households, their dreams and projects were withheld by the socialist state, which had its own interests in the realm of education.

By bringing all these articulations together - in workplaces, in households, in universities, between classes, professions, and men and women - it is reasonable to treat them jointly as manifestations of the common, because - according to theorists of commoning - it exceeds existing division between productive, unproductive and reproductive labor, between work and free time or between the working class and other unprivileged classes and groups (e.g. domestic laborers, students, peasants or lumpenproletariat). The realm of the common is not closed in any institution, space or trade - it overlaps with living labor as such. The common is a set of practices, which has potential to transform the whole life-worlds of commoners. We discover such impetus in the mentioned examples - from visions of university, which are present in the daily life of cities and factories, through efforts to relieve women from working double shifts (at home and at work) by collective forms of reproduction of households and childcare, to the unionization of the whole national labour force by "Solidarity". Together these attempts make up a commonist alternative beyond public/private dualism.

New research on the Polish popular classes' agency, mentioned above, reveals practices for instituting the common and policies of repression and control, which were tamed by the socialist state. But in criticizing the authoritarian tendencies of real socialism, we need to acknowledge at the same time multiple conditions for organizing the commons, of diverse character: institutional, infrastructural, or even symbolic and ideological. Promises of equality and emancipation of workers and women were far from being pure propaganda - they were embedded in reality. Public housing, social protections, state-sponsored vacations, and investments in culture and the reproductive sphere created a social fabric in which the common might blossom. Anti-communist offensives were not directed only at the insurgent commons, 
but also on their material background, which was mainly of socialist origin. Even if the socialist commons were corrupted by the state and ruling Party, we need to notice that practices for the common were indebted to them. If we fail to notice that connection, we are at risk of re-falling into some version of left-wing anti-communism.

It is due to the erasure of the common and to the destruction of the socialist background for the common, to the overlooking of plebeian tensions with the regime and to acceptance of the image of the socialist era as "totalitarian", that the Right could impose anti-communist hegemony in such an effective way. What's more, despite its fierce anti-communist rhetoric, the right-wing project of traditional, paternalistic society is more ready to accept the positive side of post-socialist resources and sentiments than neoliberal, free-market narration, which was dominant during phase of transition. We could describe recent Law and Justice social policies as corrupted forms of the common - as understood by Hardt and Negri (2009, 159164). Three corrupted forms of the common, which the authors of Commonwealth depicted nation, corporation and family - are central to Law and Justice's project of a sovereign state, corporate national capital and corporate Church structures, traditional family values and gender roles. The Right needs to erase the anti-capitalist character of commoning practices, but at the same time - unlike liberals - it tries to intercept and modulate them, contributing to their subjugation and corruption.

Disengagement of the common from its corrupted modifications and tackling other discourses of exclusions, which are part of the right-wing hegemony (sexism, racism, xenophobia, bigotry, anti-Semitism, anthropocentrism) seems to be impossible without contesting anti-communism, which contains in its ideological message condemnation of antihierarchic self-organization, internationalism, and anti-essentialism. These values are crucial to autonomization of the common from its limited forms and to dismantling the hegemony of the Right.

\section{How Polish is Polish anti-communism?}

Besides a particular Polish interest in contesting anti-communism, I claim that due to its spectacular character the Polish example provides us with a reformulation of the problem of contemporary forms of anti-communism in universal terms. It would be unwise to ignore Polish or Hungarian examples of extreme anti-communism as marginal ones, being a product of highly exceptional historical conditions. My point would be different: what is happening in Central Europe right now is a consequent manifestation of a global tendency to discredit not only the whole communist tradition, but - as Marxist historian Enzo Traverso (2016, 5-12) observed - to retreat from any prospects of progressive, egalitarian politics, which are now seen as "totalitarian" ones. Maybe the trajectories of the global reproduction of capitalism were 
reversed and we live in a strange time, during which - as Jan Sowa (2018, 278-279) recently pointed out - the centres of capital do not signal to the peripheries their own future anymore, but it is now the role of peripheries experiencing far-right hegemonies to foretell the future to the centres? In that sense, the recent phenomena of anti-communist leaders could be read not as a particular case of this or that country, but as a manifestation of a tendency according to which the whole world becomes post-communist or anti-communist. A Croatian political scientist, Boris Buden, proposed in his book on the era of political transition in Central Europe that maybe this region predicts what will happen to the world after the collapse not only of the Soviet Bloc, but the communist idea as such. Buden (2012) showed - based on examples drawn from the former Yugoslavia - that it would be far-right nationalistic and religious anticommunism that would fill in the gap created by the defeat of the idea of progress. His prophecies proved to be correct.

Contrary to its self-image, capitalism never was and it never will be a system advocating freedom and emancipation. The ideological promise of capitalism - that one day the whole world entangled in accumulation of capital and market exchange will be functioning like the privileged "developed" countries of the rich North - turned out to be a deceptive mirage. In order to reproduce itself on an extensive scale capital desperately needs to subjugate living labor, to divide workers and to enclose resources from their access and command. It can conduct these tasks in some regulated and consensual way only if there is accordingly strong resistance to unrestrained accumulation. It is on the peripheries that capital has always tested the limits of consent and endurance of humans and eco-systems. And where capital reigns with pure force and domination, there is a widespread need to defeat all signs of the common. Countries that experienced transitions from socialism to neoliberal capitalism - as well as former Third World states, which became victims of neocolonial practices and structural adjustment programs - uncover to us the true nature of accumulation in late crisis-driven capitalism. If there is some kind of homogenization or convergence at the horizon, it is not a world from advertising folders, but the universalization of practices already tested on the margins of the system. Structural anti-communism is on the rise and its far-right excesses will be more and more present. If there is some lesson to take from the extreme Polish case study of anti-communism, it is the following:

1) capital needs anti-communism to erase the possibility of autonomization of the common;

2) the global rise of the populist Right is possible due to subjugation and corruption of the common, which is fuelled by anti-communism and other widespread discourses of exclusion;

3) it is the common that we need to institute to defeat anti-communism. 


\section{References}

Bayer, Lili. 2018. “The New Communists”. https://www.politico.eu/article/newcommunists-hungary-poland-viktor-orban-jaroslaw-kaczynski/.

Bobako, Monika. 2017. Islamofobia jako technologia władzy: Studium z antropologii politycznej. Kraków: Universitas.

Buden, Boris. 2012. Strefa przejścia: O końcu postkomunizmu. Trans. Michał Sutowski. Warszawa: Wydawnictwo Krytyki Politycznej.

Ceplair, Larry. 2011. Anti-communism in Twentieth-Century America: A Critical History. DenverOxford-Santa Barbara: Praeger.

Cienski, Jan. 2017. "Polish conservative’s PR pushback", https://www.politico.eu/article/poland-nato-bases-germany-pis-waszczykowskicommission/.

Czerniak, Maciej. 2013. “Ksiądz Oko w Bydgoszczy: Genderyzm jest jak marksizm”. https://pomorska.pl/ksiadz-dariusz-oko-w-bydgoszczy-genderyzm-jest-jakmarksizm/ar/7422761.

De Angelis, Massimo. 2001. "Marx and Primitive Accumulation: The Continuous Character of Capital's 'Enclosures"'. The Commoner 2.

Dean, Jodi. 2019. “Anti-communism is all around us". Praktyka Teoretyczna 1(31).

Derrida, Jacques. 1994. Specters of Marx: The State of the Debt, the Work of Mourning and the New International. Trans. Peggy Kamuf. London-New York: Routledge.

Dockx, Nico and Pascal Gielen (eds.). 2018. Commonism: A New Aesthetics of the Real. Antwerp: valiz.

Drozda, Łukasz. 2015. Lewactwo: Historia dyskursu o polskiej lewicy radykalnej. Warszawa: Książka i Prasa.

Durman, Natalia. 2018. “Burza po słowach Donalda Tuska o ‘bolszewikach’: Tak się tłumaczy”. https://wiadomosci.wp.pl/burza-po-slowach-donalda-tuska-obolszewikach-tak-sie-tlumaczy-6316145891067521a.

Fidelis, Małgorzata. 2014. Women, Communism and Industrialization in Postwar Poland. Cambridge: Cambridge University Press.

Gerrits, André. 2009. The Myth of Jewish Communism: A Historical Interpretation. New York: Lang.

Golinczak, Michalina. 2019. “Communism as General Crime: An Attempt At Analysing AntiCommunist Discourse in Contemporary Poland”. Praktyka Teoretyczna 1(31).

Grabowska, Małgorzata. 2018. Zerwana genealogia: Driałalność społecæna i polityczna kobiet po 1945 roku a wspótczesny polski ruch kobiecy. Warszawa: Scholar.

Gross, Jan Tomasz. 2007. Fear: Anti-Semitism in Poland after Auschwit:. New York: Random House. 
Grzymski, Jan. 2016. Powrót do Europy - polski dyskurs: Wyznaczanie perspektywy krytycznej. Warszawa: Oficyna Wydawnicza Uczelni Lazarskiego.

Hardt, Michael and Antonio Negri. 2009. Commonwealth. Cambridge: The Belknap Press of Harvard University Press.

Hardy, Jane. 2009. Poland's New Capitalism. London: Pluto Press.

Harvey, David. 2010. The Enigma of Capital and the Crises of Capitalism. New York-Oxford: Oxford University Press.

Holubec, Stanislav and Agnieszka Mrozik. 2018. "Introduction: Historical Memory of European Communisms Before and After 1989". In Historical Memory of Central and East European Communism, eds. Stanislav Holubec and Agnieszka Mrozik. New York-Oxon: Routledge.

Judt, Tony. 2011. A Grand Illusion? An Essay on Europe. New York-London: New York University Press.

Kenney, Padraic. 1997. Rebuilding Poland: Workers and Communists, 1945-1950. Ithaca: Cornell University Press.

Klein, Naomi. 2007. The Shock Doctrine: The Rise of Disaster Capitalism. New York: Metropolitan Books.

Kłoszewski, Jakub. 2017. "Kaczyński: obowiązującą Konstytucję można nazwać postkomunistyczna". https://wiadomosci.wp.pl/kaczynski-obowiazujaca-konstytucjemozna-nazwac-postkomunistyczna-6108010390714497a.

Koć, Justyna. 2018. “Dr Marek Migalski: To wobec własnego obozu Kaczyński mógłby dziś krzyczeć 'komuniści i złodzieje”". https://wiadomo.co/dr-marek-migalski-to-wobecwlasnego-obozu-kaczynski-moglby-dzis-krzyczec-komunisci-i-zlodzieje/.

Kowalewski, Mariusz. 2018. "Portal tvp.info ujawnia: Będzie dezubekizacja w szkolnictwie wyższym”. https://www.tvp.info/35692716/portal-tvpinfo-ujawnia-bedziedezubekizacja-w-szkolnictwie-wyzszym.

Kowalik, Tadeusz. 2012. From Solidarity to Sellout: The Restoration of Capitalism in Poland. New York: Monthly Review Press.

Kowalska, Dorota. 2013. "Giertych: PiS to formacja wręcz postkomunistyczna. Kaczyński wraca do cytatów z Marksa i Lenina”. https://polskatimes.pl/giertych-pis-to-formacjawrecz-postkomunistyczna-kaczynski-wraca-do-cytatow-z-marksa-i-lenina/ar/985796/1.

Laclau, Ernesto. 2000a. "Identity and Hegemony: The Role of Universality in the Constitution of Political Logics”. In Judith Butler, Ernesto Laclau and Slavoj Žižek. Contingency, Hegemony, Universality: Contemporary Dialogues on the Left. London-New York: Verso.

Laclau, Ernesto. 2000b. "Structure, History and the Political". In Judith Butler, Ernesto Laclau and Slavoj Žižek. Contingency, Hegemony, Universality: Contemporary Dialogues on the Left. London-New York: Verso. 
Laclau, Ernesto. 2007. Emancipation(s). London-New York: Verso.

Laclau, Ernesto and Chantal Mouffe. 2001. Hegemony and Socialist Strategy: Towards a Radical Democratic Politics. London-New York: Verso.

Lefort, Claude. 1988. Democracy and Political Theory. Trans. David Macey. Cambridge-Oxford: Polity Press.

Leszczyński, Adam. 2018. “Czy Marks 'zachęcał do rewolucyjnego holokaustu’? Anatomia pewnej manipulacji”. https://oko.press/czy-marks-zachecal-do-rewolucyjnegoholokaustu-anatomia-pewnej-manipulacji/.

Liebman, Marcel and Ralph Miliband. 1984. "Reflections on Anti-Communism". Socialist Register 21.

Luxmoore, Matthew. 2018. "Poles Apart: The Bitter Conflict over a Nation's Communist History". https:/ /www.theguardian.com/news/2018/jul/13/poles-apart-the-bitterconflict-over-a-nations-history-poland-monuments-communism-soviet-union.

Majewska, Ewa. 2018. Kontrpubliczności ludowe i feministyczne: Wczesna "Solidarność" i Czarne Protesty. Warszawa: Książka i Prasa.

Majmurek, Jakub and Piotr Szumlewicz. 2010. "Fakty i mity o PRL-u”. In PRL bez uprzedzeń, eds. Jakub Majmurek and Piotr Szumlewicz. Warszawa: Instytut Wydawniczy Książka i Prasa.

Majmurek, Jakub, Kuba Mikurda and Jan Sowa. 2011. Un événement dans la glacière: Le Carnaval de Solidarnosc (1980-81) comme jaillissement de l'imagination politique. In L'idee du communisme 2, eds. Alain Badiou and Slavoj Žižek. Paris: Éditions Lignes.

Marzec, Wiktor. 2016. Rebelia i reakcja: Rewolucja 1905 roku i plebejskie doświadczenie polityczne. Kraków: Universitas.

Mezzadra, Sandro and Brett Neilson. 2017. "On the Multiple Frontiers of Extraction: Excavating Contemporary Capitalism”. Cultural Studies 31(2-3).

Millard, Frances. 2010. Democratic Elections in Poland, 1991-2007. New York-Oxon: Routledge.

Mouffe, Chantal. 2005. On the Political. Abingdon-New York: Routledge.

Mrozik, Agnieszka. 2014. "Poza nawiasem historii (kobiet), czyli po co nam dziś komunistki". Wakat On-line 3.

Negri, Antonio. 2008. Goodbye Mr Socialism. New York: Seven Stories Press.

Niemitz, Dorota. 2016. "Poland Adopts New Anti-Communist Law". https://www.wsws.org/en/articles/2016/05/14/pola-m14.html.

Olech, Michał. 2018. “Arłukowicz: Tusk nie przekroczył absolutnie żadnej granicy w wypowiedzi o bolszewikach”. http://300polityka.pl/live/2018/11/11/arlukowicz-tusknie-przekroczyl-absolutnie-zadnej-granicy-w-wypowiedzi-o-bolszewikach/.

Ost, David. 2005. Defeat of Solidarity: Anger and Politics in Postcommunist Europe. Ithaca and London: Cornell University Press. 
Pielużek, Marcin. 2016. "Identity and Values of the Polish and British Extreme Right". In There's More to Fear than Fear Itself: Fears and Anxieties in the 21st Century, eds. Selina Doran, Michael Bethan and Izabela Dixon. Oxford: Inter-Disciplinary Press.

Prozorov, Sergei. 2011. "The other as past and present: Beyond the logic of 'temporal othering' in IR theory". Review of International Studies 37(3).

Rae, Gavin. 2008. Poland's Return to Capitalism: From the Socialist Bloc to the European Union. London and New York: Tauris Academic Studies.

Shields, Stuart. 2012. “Opposing Neoliberalism? Poland's renewed populism and postcommunist transition". Third World Quarterly 33(2).

Siermiński, Michał. 2016. Dekada przetomu. Polska lewica opozycyjna 1968-1980: Od demokracji robotniczej do narodowego paternalizmu. Warszawa: Książka i Prasa.

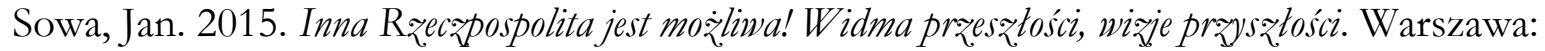
W.A.B.

Sowa, Jan. 2018. "Do Algorithms Dream of Social Strike? Review of Antonio Negri and Michael Hardt's Assembly”. Praktyka Teoretyczna 1(27).

Staniszkis, Jadwiga. 1991. The Dynamics of Breakthrough in Eastern Europe: The Polish Experience. Transl. Chester A. Kisiel. Berkeley-Los Angeles-Oxford: University of California Press.

Szczęśniak. Agata. 2017. "Petru wyklucza Razem, bo to komuniści: Zandberg grozi Petru sądem: 'Jesteśmy z tradycji socjalistycznej”'. https://oko.press/petru-wykluczakomunistow-zandberg-grozi-petru-sadem/.

Szopa, Katarzyna. 2019. "Roses or Bread? Anti-Communist Narration in Feminist Readings of Anna Świrszczyńska’s Poetry”. Praktyka Teoretyczna 1(31).

Tazbir, Janusz. 2014. Polska przedmurzem Europy. Warszawa: Wydawnictwo Książkowe Twój Styl.

Thomas, Peter D. 2009. The Gramscian Moment: Philosophy, Hegemony and Marxism. LondonBoston: Brill.

Tischner, Józef. 1992. Etyka Solidarności i Homo Sovieticus. Kraków: Społeczny Instytut Wydawniczy Znak.

Traverso, Enzo. 2016. Left-Wing Melancholia: Marxism, History and Memory. New York: Columbia University Press.

Walicki, Andrzej. 2005. "Nieporozumienia wokół antykomunizmu”. http://www.omp.org.pl/stareomp/index835e.html?module $=$ subjects\&func $=$ viewpage \&pageid $=258$.

Wielgosz, Przemysław. 2017. "Konsens antykomunistyczny”. http://lewica.pl/?id=31739\&tytul=Przemys\%B3aw-Wielgosz:-Konsensantykomunistyczny. 
Wielgosz, Przemysław. 2019. "From Anti-Communist Consensus to Anti-anti-communism". Praktyka Teoretyczna 1(31).

Woods, Jeff R. 2004. Black Struggle, Red Scare: Segregation and Anti-Communism in the South, 19481968. Baton Rouge: Louisiana State University Press.

Van Dongen, Luc, Stéphanie Roulin and Giles-Scott-Smith. 2014. Transnational AntiCommunism and the Cold War: Agents, Activities and Network. Basingstoke: Palgrave Macmillan.

Zysiak, Agata. 2016. Punkty za pochodzenie: Powojenna modernizacja i uniwersytet w robotniczym mieście. Warszawa: Nomos.

Žižek, Slavoj. 2000. “Class Struggle or Postmodernism? Yes, please!”. In Judith Butler, Ernesto Laclau and Slavoj Žižek. Contingency, Hegemony, Universality: Contemporary Dialogues on the Left. London and New York: Verso.

Žižek, Slavoj. 2009. "Post-Wall”. London Review of Books 31(22). 
Lukasz Moll - philosopher and sociologist, he finished his $\mathrm{PhD}$ at the University of Silesia in Katowice. His dissertation was devoted to the limits of European universalism in poststructuralist political philosophy. Currently he's associated with the Institute of Sociology and Philosophy of the Polish Academy of Sciences in Warsaw, where he is principal investigator in the project "The Idea of Europe in the context of migration crisis" (funded by the National Science Centre). He's accepted as a fellow to participate in the seminar with Étienne Balibar at the New School of Social Research in New York. Member of the editorial board of Praktyka Teoretyczna.

\section{ADDRESS:}

The Institute of Philosophy and Sociology

Polish Academy of Sciences

Nowy Świat 72

00-330 Warszawa

EMAIL: lukasz.moll89@gmail.com

Citation: Moll, tukasz. 2019. "Erasure of the Common: From Polish Anti-Communism to Universal Anti-Capitalism” Praktyka Teoretyczna 1(31): 118-145.

DOI: $10.14746 /$ prt.2019.1.6

\section{AUTOR: Łukasz Moll}

TYTUŁ: Wymazywanie tego, co wspólne: od polskiego antykomunizmu do uniwersalnego antykapitalizmu

ABSTRAKT: Przedmiotem artykułu jest obecny przyrost znaczenia dyskursów antykomunistycznych na przykładzie polskiego antykomunizmu. Cel artykułu jest dwojaki. Po pierwsze, by zweryfikować użyteczności teorii hegemonii dla krytyki antykomunizmu. Twierdzę, że teoria ta pozostaje przydatna jako narzędzie analityczne pozwalające rozpoznać praktyczne zastosowania antykomunizmu w rywalizacji politycznej, ale okazuje się niezdolna do konceptualizacji bardziej systemowych i nieoczywistych przejawów logiki antykomunistycznej w maszynerii współczesnego kapitalizmu. Dlatego proponuję alternatywną propozycję interpretacji zjawiska antykomunizmu - opartą głównie na postoperaistycznym marksizmie dobra wspólnego oraz na lekcjach teoretycznych, jakie wypływają z najnowszych badań nad ludowymi, oddolnymi praktykami społecznymi w Polsce. Po drugie, przedstawia hipotezę, wedle której właściwe zrozumienie partykularnego przykładu polskiego antykomunizmu może okazać się pomocne w rozpoznaniu funkcjonowania 
uniwersalnego antykomunizmu, rozumianego jako reakcja na walki mające na celu instytucję tego, co wspólne.

SŁOWA KLUCZOWE: antykomunizm, dobro wspólne, antykapitalizm, hegemonia, polska polityka 